\title{
PERSEPSI PERAWAT TENTANG PENJAMINAN MUTU KESELAMATAN PASIEN OLEH KEPALA RUANGAN
}

\author{
ISWATI \\ AKADEMI KEPERAWATAN ADI HUSADA SURABAYA \\ iswatisaja@yahoo.com
}

\begin{abstract}
ABSTRAK
Penerapan tindakan keselamatan pasien membuat pasien bebas dari cidera yang tidak seharusnya terjadi, namun masih didapatkan adanya insiden keselamatan pasien yang dilakukan perawat akibat kurangnya penerapan penjaminan mutu keselamatan pasien oleh kepala ruangan. Penelitian ini bertujuan untuk mengetahui karakteristik dan persepsi perawat tentang penjaminan mutu keselamatan pasien oleh kepala ruangan di Rumah Sakit. Jenis penelitian ini adalah deskriptif, dengan populasi dan sampel 30 perawat, menggunakan total sampling. Variabel penelitian yaitu persepsi perawat tentang penjaminan mutu keselamatan pasien. Skala data yang digunakan ordinal. Data diperoleh melalui kuesioner serta dianalisis secara deskriptif. Penerapan penjaminan mutu keselamatan pasien oleh kepala ruangan dipersepsikan dalam kategori baik (93.4\%) oleh perawat. Persepsi perawat tentang penjaminan mutu keselamatan pasien oleh kepala ruangan dipengaruhi oleh faktor struktural, fungsional, personal, situasional. Namun masih diperlukan peningkatan mutu dan sosialisasi tentang penjaminan mutu oleh kepala ruangan yang lebih intensif agar perawat dapat lebih terlibat dalam upaya penjaminan mutu keselamatan pasien.
\end{abstract}

Kata kunci: Penjaminan mutu, keselamatan pasien, kepala ruang, persepsi

\section{ABSTRACT}

Introduction: Application of patient safety measures to make the patient free from injuries that are not supposed to happen, but still found the incident nurse performed patient safety due to the lack of implementation of quality assurance of the safety of the patient by the nurse unit manager. This study aims to determine the characteristics and perceptions of nurses about patient safety quality assurance by the nurse unit manager. Methods: The study was descriptive, with a population and a sample of 30 nurses, using total sampling. Variable research that the perception of nurses about patient safety quality assurance. Data used ordinal scale. Data obtained through questionnaires and analyzed descriptively. Result: The application of quality assurance of the safety of the patient by the nurse unit manager is perceived in either category $(93.4 \%)$ by nurses. Discussion: Perception of nurses about patient safety quality assurance by the nurse unit manager influenced by the structural, functional, personal, situational. But the nurse unit manager is still needed to improve the quality and dissemination of quality assurance more intensive for nurses to be involved in the quality assurance of patient safety.

Keywords: quality assurance, patient safety, the nurse unit manager, perception

\section{PENDAHULUAN}

Keselamatan pasien telah menjadi isu dunia yang perlu mendapat perhatian bagi sistem pelayanan kesehatan. Keselamatan pasien merupakan prinsip dasar dari pelayanan kesehatan yang memandang bahwa keselamatan merupakan hak bagi setiap pasien dalam menerima pelayanan kesehatan. Keselamatan pasien juga dapat diartikan sebagai suatu keadaan pasien bebas dari cidera yang tidak seharusnya terjadi atau bebas dari cidera yang berisiko dapat terjadi ${ }^{8}$. World Health Organization (WHO) Collaborating Center for Patient Safety Solusions bekerja sama dengan Joint Comission International telah memasukkan masalah keselamatan pasien dengan menerbitkan enam program kegiatan keselamatan pasien pada 2005 dan sembilan panduan solusi keselamatan pasien di rumah sakit pada 
2007. Kemenkes Republik Indonesia menjadikan hak pasien sebagai standar pertama pada tujuh standar keselamatan pasien rumah sakit ${ }^{4}$.

Data tentang KTD di Indonesia, dikategorikan masih langka untuk ditemukan apalagi untuk kejadian nyaris cidera, namun permasalahan malpraktik masih banyak terungkap di media informasi ${ }^{12}$. Hal ini terjadi karena standar pelayanan kesehatan di Indonesia masih kurang optimal jika dibandingkan dengan negara maju seperti Amerika dan Inggris. Indonesia telah mencanangkan "Gerakan Keselamatan Pasien Rumah Sakit" sejak 2005 dan keselamatan pasien sudah dilaksanakan di rumah sakit, namun penerapannya masih belum komprehensif

Laporan insiden keselamatan pasien di Indonesia berdasarkan provinsi pada tahun 2007 ditemukan provinsi DKI Jakarta menempati urutan tertinggi yaitu $37.9 \%$ diantara provinsi lainnya (Jawa Tengah 19.5\%, DI Yogyakarta $13.8 \%$, Jawa Timur 11.7\%, Aceh 10.7\%, Sumatra Selatan 6.9\%, Jawa Barat 2.8\%, Bali 1.4\% serta Sulawesi Selatan 0.7\%). Bidang spesialisasi unit kerja menyebutkan paling banyak ditemukan pada unit penyakit dalam, bedah dan anak yaitu sebesar $56.7 \%$ dibandingkan unit kerja lain. Sedangkan untuk pelaporan jenis kejadian nyaris cidera (KNC) lebih banyak dilaporkan sebesar 47.6\% dibandingkan kejadian tidak diharapkan (KTD) sebesar $40.2 \%{ }^{8}$. Sedangkan berdasarkan wawancara dengan Ketua Komite Keselamatan Pasien Rumah Sakit Adi Husada Undaan Wetan Surabaya pada 3 Maret 2013, masih didapatkan insiden keselamatan pasien pada tahun 2012, tetapi terkait dengan angka dari insiden keselamatan pasien peneliti tidak mendapatkan ijin untuk menampilkan data tersebut.

Faktor-faktor yang dapat melatarbelakangi terjadinya insiden keselamatan pasien diantaranya: Kebijakan dan prosedur yang tidak adekuat, kurang optimalnya dokumentasi atau kurang baiknya pencatatan atau standar operasional prosedur klinis yang kuat. Kegagalan peralatan atau perlengkapan juga dapat menyebabkan insiden keselamatan pasien, karena instruksi yang tidak adekuat dan peralatan yang dirancang dengan buruk dapat mengakibatkan pasien cidera. Selain itu, transfer pengetahuan di rumah sakit juga dibutuhkan untuk mencegah insiden keselamatan pesien, sebab dengan kurangnya orientasi atau pelatihan pada petugas pelayanan kesehatan maka tingkat pengetahuan dalam menjalankan tugas juga kurang. Hal-hal yang berhubungan dengan pasien seperti identifikasi yang tidak tepat, pengkajian pasien yang tidak lengkap, kegagalan memperoleh persetujuan pasien, pendidikan, dan pengetahuan pasien yang tidak adekuat juga dapat mempengaruhi terjadinya insiden keselamatan pasien. Faktor lain yang dapat menyebabkan terjadinya insiden keselamatan pasien adalah lingkungan kerja. Insiden dapat terjadi ketika kepala ruangan, perawat, dan staf lain sibuk karena sumber daya manusia yang kurang memadai, serta pengawasan atau supervisi oleh kepala ruangan yang tidak adekuat ${ }^{8}$.

Adapun dampak yang dapat terjadi akibat dari faktor-faktor diatas adalah terjadinya insiden keselamatan pasien antara lain: Kesalahan dalam mengidentifikasi pasien, kurang efektifnya komunikasi antar petugas kesehatan, kurang adekuatnya pengawasan terhadap keamanan obat dan cairan, ketidaktepatan identifikasi lokasi, prosedur, dan pasien operasi, terjadinya infeksi serta pasien jatuh terkait pelayanan kesehatan yang dapat menyebabkan cidera bahkan kematian 4. Untuk mencegah terjadinya insiden keselamatan pasien diperlukan peran dan fungsi kepala ruangan yang adekuat terkait penjaminan mutu keselamatan pasien yang berkesinambungan dan sistematis dengan melakukan pengukuran dan peningkatan mutu seperti: Menunjuk dan membentuk anggota penjaminan mutu keselamatan pasien di ruangan, mengadakan pertemuan atau rapat untuk 
menyusun program penjaminan mutu keselamatan pasien di ruangan, mengukur dan menilai mutu keselamatan pasien, membahas penyebab terjadinya masalah atau hambatan dalam penjaminan mutu keselamatan pasien, mengkomunikasikan standar operasional prosedur penjaminan mutu keselamatan pasien, menginstruksikan pelaksanaan program penjaminan mutu keselamatan pasien oleh perawat pelaksana, melakukan penilaian terhadap tindakan penjaminan mutu keselamatan pasien yang dilakukan oleh perawat pelaksana. Berdasarkan hasil survei pendahuluan pada April 2013 dari 10 perawat, 8 menyatakan belum mengetahui program apa saja yang telah dilakukan oleh kepala ruang untuk menjamin keselamatan pasien di ruangan. B erdasarkan uraian diatas, peneliti tertarik untuk mengidentifikasi persepsi perawat tentang penjaminan mutu keselamatan pasien oleh kepala ruangan.

\section{METODE PENELITIAN}

Jenis penelitian yang digunakan adalah penelitian deskriptif, penelitian ini dilakukan untuk mengeksplorasi persepsi perawat tentang peran dan fungsi kepala ruangan dalam penjaminan mutu keselamatan pasien. Penelitian ini dilakukan pada Mei 2013 di Ruang E3 dan ZD3 Rumah Sakit Adi Husada Undaan Wetan Surabaya. Populasinya seluruh perawat di Ruang E3 dan ZD3 Rumah Sakit Adi Husada Undaan Wetan Surabaya sebanyak 30 orang. Teknik sampling menggunakan Non probability sampling yaitu total sampling. Variabel yang diteliti: Persepsi perawat tentang penjaminan mutu keselamatan pasien. Alat ukur yang digunakan untuk pengumpulan data adalah kuesioner. Analisa data dilakukan secara deskriptif.

\section{HASIL}

Hasil penelitian menunjukkan ratarata usia responden adalah 33 tahun dengan Usia termuda 22 tahun dan usia tertua 55 tahun. Masa Kerja rata-rata selama 10 tahun dengan lama kerja tersingkat selama 8 bulan dan terlama selama 28 tahun. Tingkat pendidikan sebanyak $93.3 \%$ perawat memiliki pendidikan D3 Keperawatan. Sedangkan $6.7 \%$ saja yang berpendidikan S1 Keperawatan. Hampir setengah perawat yaitu sebanyak 43.3\% diruang E3 dan ZD3 Rumah Sakit Adi Husada Undaan Wetan Surabaya pernah mengikuti pelatihan keselamatan pasien. Sedangkan 56.7\% belum pernah mengikuti pelatihan tentang keselamatan pasien.

Data Khusus mengenai persepsi perawat tentang penjaminan mutu keselamatan pasien oleh kepala ruangan menunjukkan sebanyak 93.4\% memiliki persepsi yang baik, dan $6.6 \%$ yang mempersepsikan penjaminan mutu keselamatan pasien oleh kepala ruangan cukup baik.

\section{PEMBAHASAN}

Berdasarkan hasil penelitian menunjukkan $(93,4 \%)$ memiliki persepsi yang baik tentang penjaminan mutu keselamatan pasien oleh kepala ruangan. Hal ini menandakan kepala ruangan telah menerapkan penjaminan mutu keselamatan pasien dengan baik.

Persepsi dapat dipengaruhi oleh empat faktor meliputi: Faktor struktural, faktor fungsional, faktor personal, dan faktor situasional ${ }^{13}$.

Faktor pertama yang mempengaruhi persepsi adalah faktor struktural, yang dihasilkan dari bentuk stimulus serta efekefek netral yang ditimbulkan dari sistem saraf individu. Faktor ini berhubungan dengan usia seseorang. Usia adalah umur individu yang terhitung mulai saat dilahirkan sampai berulang tahun ${ }^{8}$. Perawat pada penelitian ini rata- rata berusia 33 tahun (dewasa). Usia perawat ini merupakan usia produktif dan berada pada tahap pemantapan karir. Usia mempengaruhi pembentukan sebuah persepsi terhadap penilaian kinerja kepala ruangan, seseorang yang lebih dewasa memiliki pola pikir yang dinamis dan membutuhkan banyak pertimbangan dalam menilai suatu keadaan. Dengan rata-rata usia perawat diatas, dapat disimpulkan bahwa banyak pertimbangan dalam memberikan penilaian terhadap kinerja 
kepala ruangan sehingga perawat memiliki persepsi yang baik dalam menerapkan penjaminan mutu keselamatan pasien di ruang E3 dan ZD3 Rumah Sakit Adi Husada Undaan Wetan.

Faktor kedua yang mempengaruhi persepsi adalah faktor fungsional, yang dihasilkan dari kebutuhan, kegembiraan (suasana hati), pelayanan, dan pengalaman masa lalu. Dalam hal ini, pengalaman masa lalu erat kaitannya dengan masa kerja. Karakteristik masa kerja responden menunjukkan bahwa perawat memiliki rata-rata masa kerja selama 10 tahun dengan masa kerja terlama selama 28 tahun dan masa kerja tersingkat selama 8 bulan. Responden yang memiliki masa kerja yang lama memiliki persepsi penjaminan mutu keselamatan pasien yang lebih baik dan mendasar daripada yang memiliki masa kerja yang singkat, hal ini berpengaruh dalam persepsi responden dalam menilai kinerja kepala ruangan dalam menerapkan penjaminan mutu keselamatan pasien sehingga menghasilkan persepsi yang baik.

Faktor lain yang mempengaruhi persepsi adalah faktor personal, yang dihasilkan dari pengalaman, motivasi, dan kepribadian. Faktor personal ini berhubungan dengan pendidikan dan pelatihan yang pernah diikuti oleh perawat. Tingkat pendidikan perawat di ruang E3 dan ZD3 Rumah Sakit Adi Husada Undaan Wetan Surabaya sebagian besar adalah diploma III Keperawatan sebanyak 28 responden. Sedangkan tenaga perawat dengan pendidikan S1 Keperawatan jumlahnya masih terbatas yaitu 2 responden $(6.6 \%)$. S emakin tinggi tingkat pendidikan seseorang, makin mudah pula orang tersebut menerima informasi sehingga semakin baik pula persepsi yang dimiliki. Faktor pendidikan akan berpengaruh terhadap kemampuan dan perilaku seseorang dalam mempersepsikan sesuatu. Melalui pendidikan yang tinggi perawat akan mampu berpikir dengan kritis, kreatif dan rasional yang akan membentuk persepsinya menjadi lebih baik saat terlibat dalam kegiatan penjaminan mutu keselamatan pasien oleh kepala ruangan di ruang E3 dan ZD3 Rumah Sakit Adi Husada Undaan Wetan Surabaya.

Pelatihan merupakan bagian dari proses pendidikan yang tujuannya untuk meningkatkan kemampuan dan keterampilan khusus baik perseorangan atau sekelompok orang ${ }^{10}$. Perawat yang pernah mengikuti pelatihan keselamatan pasien dalam penelitian ini sebanyak 43,4\%. Hal ini menandakan hampir setengah dari jumlah repsonden pernah mengikuti pelatihan yang berkaitan dengan keselamatan pasien. Pelatihan memiliki kontribusi yang kecil dalam pembentukan persepsi seseorang. Pelatihan lebih meningkatkan kemampuan individual secara softskill dan hardskill sehingga dapat disimpulkan bahwa pelatihan hanya membentuk kemampuan internal dan dapat berpengaruh pada persepsi internal saja. Meskipun demikian, hasil penelitian ini menunjukkan perawat memiliki persepsi yang baik mengenai pejaminan mutu keselamatan pasien oleh kepala ruangan di ruang E3 dan ZD3 Rumah sakit Adi Husada Undaan Wetan Surabaya.

Faktor terakhir yang mempengaruhi persepsi adalah faktor situasional, yang banyak berkaitan dengan bahasa nonverbal seperti petunjuk proksemik, petunjuk kinesik, petunjuk wajah, dan petunjuk paralinguistik. Berdasarkan hasil kuesioner, penerapan penjaminan mutu keselamatan pasien yang dilakukan kepala ruangan di ruang E3 dan ZD3 Rumah Sakit Adi Husada Undaan Wetan Surabaya dipersepsikan baik oleh perawat. Hasil penelitian menunjukkan kepala ruang telah mensosialisasikan dan memberikan contoh/petunjuk tentang penerapan penjaminan mutu keselamatan pasien yang baik kepada perawat (93.4\%).

Persepsi dapat dipengaruhi oleh empat faktor meliputi: Faktor struktural, faktor fungsional, faktor personal, dan faktor situasional. Faktor pertama yang mempengaruhi persepsi adalah faktor struktural, yang dihasilkan dari bentuk stimulus serta efek-efek netral yang ditimbulkan dari sistem saraf individu. Faktor ini berhubungan dengan usia seseorang. Usia adalah Umur individu yang 
terhitung mulai saat dilahirkan sampai berulang tahun. Perawat pada penelitian ini rata-rata berusia 33 tahun (dewasa). Usia perawat ini merupakan usia produktif dan berada pada tahap pemantapan karir. Usia mempengaruhi pembentukan sebuah persepsi terhadap penilaian kinerja kepala ruangan, seseorang yang lebih dewasa memiliki pola pikir yang dinamis dan membutuhkan banyak pertimbangan dalam menilai suatu keadaan. Dengan rata-rata usia perawat diatas, dapat disimpulkan bahwa banyak pertimbangan dalammemberikan penilaian terhadap kinerja kepala ruangan sehingga perawat memiliki persepsi yang baik dalam menerapkan penjaminan mutu keselamatan pasien di ruang E3 dan ZD3 Rumah Sakit.

Faktor kedua yang mempengaruhi persepsi adalah faktor fungsional, yang dihasilkan dari kebutuhan, kegembiraan (suasana hati), pelayanan, dan pengalaman masa lalu. Dalam hal ini, pengalaman masa lalu erat kaitannya dengan masa kerja. Karakteristik masa kerja responden menunjukkan bahwa perawat memiliki ratarata masa kerja selama 10 tahun dengan masa kerja terlama selama 28 tahun dan masa kerja tersingkat selama 8 bulan. Responden yang memiliki masa kerja yang lama memiliki persepsi penjaminan mutu keselamatan pasien yang lebih baik dan mendasar daripada yang memiliki masa kerja yang singkat, hal ini berpengaruh dalam persepsi responden dalam menila ikinerja kepala ruangan dalam menerapkan penjaminan mutu keselamatan pasien sehingga menghasilkan persepsi yang baik.

Faktor lain yang mempengaruhi persepsi adalah faktor personal, yang dihasilkan dari pengalaman, motivasi, dan kepribadian. Faktor personal ini berhubungan dengan pendidikan dan pelatihan yang pernah diikuti oleh perawat. Tingkat pendidikan perawat diruang E3 dan ZD3 Rumah Sakit Adi Husada Undaan Wetan Surabaya sebagian besar adalah Diploma III Keperawatan sebanyak 28 responden. Sedangkan tenaga perawat dengan pendidikan S1 Keperawatan jumlahnya masih terbatas yaitu 2 responden $(6.6 \%)$. Semakin tinggi tingkat pendidikan seseorang, makin mudah pula orang tersebut menerima informasi sehingga semakin baik pula persepsi yang dimiliki. Faktor pendidikan akan berpengaruh terhadap kemampuan dan perilaku seseorang dalam mempersepsikan sesuatu. Melalui pendidikan yang tinggi perawat akan mampu berpikir dengan kritis, kreatif dan rasional yang akan membentuk persepsinya menjadi lebih baik saat terlibat dalam kegiatan penjaminan mutu keselamatan pasien oleh kepala ruangan diruang E3 dan ZD3 Rumah Sakit Adi Husada Undaan Wetan Surabaya. Pelatihan merupakan bagian dari proses pendidikan yang tujuannya untuk meningkatkan kemampuan dan keterampilan khusus baik perseorangan atau sekelompok orang ${ }^{10}$. Perawat yang pernah mengikuti pelatihan keselamatan pasien dalam penelitian ini sebanyak 43,4\%. Hal ini menandakan hampir setengah dari jumlah repsonden pernah mengikuti pelatihan yang berkaitan dengan keselamatan pasien. Pelatihan memiliki kontribusi yang kecil dalam pembentukan persepsi seseorang. Pelatihan lebih meningkatkan kemampuan individual secara softskill dan hardskill sehingga dapat disimpulkan bahwa pelatihan hanya membentuk kemampuan internal dan dapat berpengaruh pada persepsi internal saja. Meskipun demikian, hasil penelitian ini menunjukkan perawat memiliki persepsi yang baik mengenai pejaminan mutu keselamatan pasien oleh kepala ruangan diruang E3 dan ZD3 Rumah sakit Adi Husada Undaan Wetan Surabaya.

Faktor terakhir yang mempengaruhi persepsi adalah faktor situasional, yang banyak berkaitan dengan bahasa nonverbal seperti petunjuk proksemik, petunjuk kinesik, petunjuk wajah, dan petunjuk paralinguistik. Berdasarkan hasil kuesioner, penerapan penjaminan mutu keselamatan pasien yang dilakukan kepala ruangan di ruang E3 dan ZD3 Rumah Sakit Adi Husada Undaan Wetan Surabaya dipersepsikan baik oleh perawat. Hasil penelitian menunjukkan kepalar uang telah mensosialisasikan dan memberikan contoh/petunjuk tentang penerapan 
penjaminan mutu keselamatan pasien yang baik kepada perawat (93.4\%).

\section{SIMPULAN}

Penerapan penjaminan mutu keselamatan pasien oleh kepala ruangan di Ruang E3 dan ZD3 Rumah Sakit Adi Husada Undaan Wetan Surabaya dipersepsikan baik oleh perawat.

\section{SARAN}

Perawat hendaknya lebih terlibat secara aktif dalam kegiatan penjaminan mutu keselamatan pasien karena hasil penelitian menunjukkan perawat sudah memiliki persepsi baik tentang penjaminan mutu keselamatan pasien oleh kepala ruangan. Kepala ruangan diharapkan mempertahankan dan lebih meningkatkan penerapan dan sosialisasi penjaminan mutu keselamatan pasien diruang tersebut. Hasil penelitian ini dapat digunakan sebagai data awal penelitian berikutnya mengenai penjaminan mutu keselamatan pasien dengan memperbaiki metode pengambilan data melalui observasi secara langsung terkait penerapan penjaminan mutu keselamatan pasien yang dilakukan oleh kepala ruangan.

\section{DAFTAR PUSTAKA}

1. Abdullah, Mulat Wigati. 2006. Sosiologi. Jakarta: Grasindo.

2. Bustami. 2011. Penjaminan Mutu Pelayanan Kesehatan dan Akseptabilitasnya. Jakarta: Erlangga.

3. Dahlan, M. S. 2010. Langkahlangkah Membuat Proposal Penelitian Bidang Kedokteran \& Kesehatan. Jakarta: CV. Sagung Seto.

4. Depkes RI. 2006. Panduan Nasional Keselamatan Pasien Rumah Sakit (Patient Safety): Utamakan Keselamatan Pasien. Jakarta: Depkes RI.

5. Depkes RI. 2008. Panduan Nasional Keselamatan Pasien Rumah Sakit (Patient Safety): Utamakan Keselamatan Pasien. Edisi Kedua. Jakarta: Depkes RI.
6. Depkes RI. 2011. Panduan Nasional Keselamatan Pasien

Rumah Sakit (Patient Safety): Utamakan Keselamatan Pasien. Edisi Ketiga. Jakarta: Depkes RI.

7. Heriyanto, Bambang. 2012. Metode Penelitian Kuantitatif Teori Dan Aplikasi. Surabaya: Putra Medika Nusantara.

8. KKP-RS. 2008. Pedoman Pelaporan Insiden Keselamatan Pasien (IKP). Jakarta: KKP-RS.

9. Marquis, Bessie L. \& Carol J. Huston. 2010. Kepemimpinan dan Managemen Keperawatan: Teori dan Aplikasi. Jakarta: Erlangga.

10. Notoatmodjo, Soekidjo. 2010. Metode Penelitian Kesehatan. Jakarta: Rineka Cipta. Nursalam. 2003. Konsep dan Penerapan Metodelogi Penelitian Keperawatan. Jakarta: Selemba Medika.

11. Pohan, Imbalo S. 2006. Jaminan Mutu Layanan Kesehatan: DasarDasar Pengertian dan Penerapan. Jakarta. EGC.

12. RSCM. 2011. Buku Saku Quality dan Safety. Jakarta: RSUPN Dr. Cipto Mangunkusumo.

13. Sobur, Alex. 2003. Psikologi Umum. Bandung: Pustaka Setia.

14. Sunaryo. 2004. Psikologi untuk Keperawatan. Jakarta: EGC. 